\title{
Differential protein expression in primary breast cancer and matched axillary node metastasis
}

\author{
PHATCHARAPORN THONGWATCHARA ${ }^{1}$, WARAPORN PROMWIKORN ${ }^{2}$, CHANTRAGAN SRISOMSAP $^{4}$, \\ DARANEE CHOKCHAICHAMNANKIT ${ }^{4}$, PLEUMJIT BOONYAPHIPHAT $^{3}$ and PARAMEE THONGSUKSAI ${ }^{3}$ \\ ${ }^{1}$ Programme of Molecular Biology and Bioinformatics, ${ }^{2}$ Department of Anatomy, Faculty of Science, \\ ${ }^{3}$ Department of Pathology, Faculty of Medicine, Prince of Songkla University, Hat Yai, Songkhla 90110; \\ ${ }^{4}$ Laboratory of Biochemistry, Chulabhorn Research Institute, Bangkok 10210, Thailand
}

Received February 14, 2011; Accepted March 22, 2011

DOI: $10.3892 /$ or.2011.1266

\begin{abstract}
Axillary lymph node (ALN) metastasis is a key step of tumor progression in breast cancer and is associated with an unfavorable prognosis. However, the mechanisms of this process are not well understood. Proteomic technologies have led to identification of specific protein markers and a better understanding of the cellular processes. To explore this, differential protein expression was analyzed between nodepositive breast carcinoma and node-negative breast carcinoma (11 samples) and between primary breast carcinoma and matched metastatic ALN (five pairs) using a combination of 2D-SDS-PAGE and LC-MC/MS. Of the total 678 protein spots, 19 proteins were up-regulated and 3 proteins were down-regulated in node-positive breast carcinomas compared to node-negative breast carcinomas. Four up-regulated proteins were identified, namely Annexin 5, carbonic anhydrase I, peroxiredoxin 6 and proteasome $\alpha 2$ subunit. For proteins altered in metastatic ALN compared to primary tumors, 6 of 14 up-regulated proteins were identified: heat shock $70 \mathrm{kDa}$ protein 5 , protein disulfide isomerase, prolyl 4-hydroxylase $\beta$ subunit precursor, lactate dehydrogenase $B$, triosephosphate isomerase 1 and $\beta$-tubulin and 5 of 23 down-regulated proteins were identified including $90 \mathrm{kDa}$ heat shock protein, chain A apo-human serum transferrin, chain A $\alpha 1$-antitrypsin, enolase 1 and macrophage migration inhibitory factor. Immunohistochemistry showed stronger immunostaining for $\beta$-tubulin in metastatic ALN compared to primary breast tumor. All of the identified proteins function in various processes involved in cell survival and growth. Our results suggest that these processes are critical for tumor progression and metastasis and the proteins identified could be candidate markers of clinical usefulness.
\end{abstract}

Correspondence to: Dr Paramee Thongsuksai, Department of Pathology, Faculty of Medicine, Prince of Songkla University, Hat Yai, Songkhla 90110, Thailand

E-mail: tparamee@gmail.com

Key words: 2D-PAGE, breast cancer, axillary node metastasis, proteomics, protein markers, mass spectrometry

\section{Introduction}

Breast cancer is an important health burden worldwide. It is by far the most frequent cancer in women (23\% of all cancers), with an estimated 1.15 million new cases in 2002, ranking second overall when both genders are considered together (1). In Thailand, though the incidence is low, it has been continuously increasing throughout the last few decades $(2,3)$. Nowadays, breast cancer has become one of the major focus of public health campaigns for cancer prevention and control in our country.

Several clinicopathological factors have been recognized as prognostic indicators for disease outcome with breast cancer $(4,5)$. Among these, tumor size and axillary lymph node (ALN) metastasis are most important. In one study, patients with a small tumor $(<2 \mathrm{~cm})$ and no ALN metastasis had a 5-year survival rate over $95 \%$ while those with large tumor $(>5 \mathrm{~cm})$ with ALN metastasis, the survival rate was only $45 \%(4,5)$. Therefore, detection of breast cancer at the early stage or identification of factors that help predict ALN metastasis is of prime importance.

It is well known that cancer cell transformation and progression are extremely complex events involving mutation or deregulation of a variety of genes controlling cell proliferation, differentiation and cell death $(6,7)$. Different proteins may be up-regulated or down-regulated simultaneously and provoke distinct cell functions. Therefore, the analysis of a single or few proteins is far from the prediction of the clinical outcome. The newly developed proteomics technologies which can identify hundreds of altered proteins in a single experiment, have provided a great opportunity for the identification of novel protein markers (8).

In this study, we attempted to identify proteins that were altered during tumor progression and metastasis of breast cancer. We utilized a proteomics approach using a combination of 2D-SDS-PAGE and mass spectrometry to determine differentially expressed proteins in primary breast cancers with and without ALN metastasis and proteins that altered between primary tumors and their matched metastatic ALN. These results may provide a better understanding of cellular mechanism of tumor progression and metastasis and also help identify candidate markers for further clinical usefulness. 


\section{Materials and methods}

Tissue samples. Fresh tissue of breast cancer and metastatic ALN were obtained at the time of surgical resection from 11 breast cancer patients of Songklanagarind Hospital, Faculty of Medicine, Prince of Songkla University, Songkhla. The selected tissues were removed from the resection specimens and stored at $-70^{\circ} \mathrm{C}$ until processing. The patients were staged according to the American Joint Committee on Cancer (AJCC) 6th Edition Staging Manual (9). Histopathological characteristics were reviewed and confirmed by a single pathologist before use in the study. The research protocol was approved by the Research Ethics Committee of the faculty.

Protein extraction and two-dimensional gel electrophoresis. To obtain the representative area, each sample was sectioned in $0.5 \mu \mathrm{m}$ thickness at $-20^{\circ} \mathrm{C}$, stained with routine $\mathrm{H} \& \mathrm{E}$ and examined under light microscopy. If the tissue sections still contain undesirable areas, the original gross tissues were trimmed, processed for histological procedures, and examined until the specific area was acquired. The representative frozen tissues were ground with lysis buffer containing $7 \mathrm{M}$ urea, $2 \mathrm{M}$ thiourea, 4\% CHAPS, $1 \%$ DTT and 2\% IPG buffer (pH 3-10). The mixture was then frozen with liquid nitrogen, and thawed. The protein mixture was centrifuged at $14,000 \mathrm{rpm}$ for $15 \mathrm{~min}$ at $4^{\circ} \mathrm{C}$. The supernatant was taken as protein extract for further analysis. Protein concentration was determined using Protein Assay Dye Reagent Concentrate (Bio-Rad) based on Bradford's method using bovine serum albumin as a standard.

The proteins were separated by $13-\mathrm{cm}$ immobilized $\mathrm{pH}$ gradient (IPG) strips, pH 3-10 range (linear) followed by SDS-PAGE. Trace contaminants in the protein solution were removed using 2-D Clean-Up Kit (Amersham Biosciences) according to the manufacturer's instruction. Protein extract $(75 \mu \mathrm{g})$ were subjected to IEF in the first step of protein separation for the total $18.8 \mathrm{kVh}$ at $20^{\circ} \mathrm{C}$. The focused IPG strips were then equilibrated with equilibration buffer I containing SDS and $65 \mathrm{mM}$ DTT for $15 \mathrm{~min}$ and with equilibration buffer 11 containing SDS and $135 \mathrm{mM}$ iodoacetamide for $15 \mathrm{~min}$. The second step of protein separation was performed by $12 \%$ SDS-PAGE. The protein spots were visualized by silver staining.

Image analysis. The stained gels were scanned with an Image Scanner ${ }^{\mathrm{TM}}$ (Amersham Biosciences) at 300 dpi resolution, and the images were saved as MEL files. The images were further processed by 2D gel analysis software, Image Master 2D Platinum (Amersham Biosciences). Cropping of the clusters of spots of all images was performed. Protein spots in the cropped images were detected and matched to a reference gel. The missing spots were added manually to the reference gel and all matched gels. Mismatched spots were edited and then the intensities of protein spots were analysed. To eradicate the error of the different levels of stained protein, normalisation was made by calculating a percentage ratio of individual spot volume to the total volume of protein spots in each gel image.

The comparison of mean intensities of protein spots were compared statistically using t-test for two comparison sets: i) breast cancers from patients with node-negative $\left(\mathrm{Tn}^{-}\right)$ and breast cancers from patients with node-positive disease $\left(\mathrm{Tn}^{+}\right)$; and ii) primary breast cancers from patients with node-positive disease $\left(\mathrm{Tn}^{+}\right)$and matched metastatic ALN (L) (paired t-test). The level of significance of p-value was set at $<0.05$.

In-gel digestion with trypsin. Protein spots were washed with $100 \mu \mathrm{l}$ de-ionized water, 3 times. To destain silver nitrate from the proteins, $30-50 \mu \mathrm{l}$ of $15 \mathrm{mM} \mathrm{K}_{3} \mathrm{Fe}(\mathrm{CN})_{6}$ and $50 \mathrm{mM} \mathrm{Na}_{2} \mathrm{~S}_{2} \mathrm{O}_{3}$ were added and vortexed for 1-2 min. This procedure was repeated until the gel pieces were clear. Afterwards, those gel pieces were washed 3 times with $50 \mu \mathrm{l}$ of $25 \mathrm{mM} \mathrm{NH}_{4} \mathrm{HCO}_{3}$, 10 min each time and then the gel was dried completely by SpeedVac. Disruption of disulfide bonds between cysteine residue within polypeptide chains was achieved by adding $50 \mu \mathrm{l}$ of $0.1 \mathrm{mM} \mathrm{NH}_{4} \mathrm{HCO}_{3}, 10 \mathrm{mM}$ DTT, and $1 \mathrm{mM}$ EDTA and incubated at $45^{\circ} \mathrm{C}$ for $45 \mathrm{~min}$. The solvent was discarded and quickly replaced by a freshly prepared solution of $100 \mathrm{mM}$ of iodoacetamide in $0.1 \mathrm{mM} \mathrm{NH} \mathrm{HCO}_{3}$. The solution was then agitated at room temperature in the dark for $30 \mathrm{~min}$. The solution was removed and gel pieces were washed 3 times with $50 \mu 1$ iodoacetamide washing solution $(0.05 \mathrm{mM}$ Tris- $\mathrm{HCl}, \mathrm{pH} 8.5$, and $50 \%$ acetronitrile), at $10 \mathrm{~min}$ each time. The gels were entirely dried. Working trypsin solution (30 $\mu$ l) (resuspended trypsin in $0.1 \%$ acetic acid, $0.05 \mathrm{mM}$ Tris- $\mathrm{HCl}, 10 \%$ acetronitrile, $1 \mathrm{mM} \mathrm{CaCl}{ }_{2}, \mathrm{pH} 8.5$ ) was added and incubated, accompanied with stirring at $37^{\circ} \mathrm{C}$ overnight. The mixture was removed to a new tube. The gels were soaked in $2 \%$ trifluoroacetic acid at $60^{\circ} \mathrm{C}$ for $30 \mathrm{~min}$ and vortexed continuously. The gel pieces were placed in $40 \mu \mathrm{l}$ of digestive buffer $\left(0.05 \mathrm{mM}\right.$ Tris- $\mathrm{HCl}, 1 \mathrm{mM} \mathrm{CaCl}_{2}$, $\mathrm{pH} \mathrm{8.5)} \mathrm{and} \mathrm{agitated} \mathrm{at} 30^{\circ} \mathrm{C}$ for $10 \mathrm{~min}$. Subsequently, the gels were put in a sonicator for $5 \mathrm{~min}$. Forty microliters of $100 \%$ acetronitrile was added and incubated at $30^{\circ} \mathrm{C}$ for $10 \mathrm{~min}$. The mixture was again placed in sonicator for $5 \mathrm{~min}$. Next, the mixture was pulled on to a new tube and $40 \mu 1$ of $5 \%$ formic acid and $100 \%$ acetronitrile (1:1) were added and incubated in the agitator at $30^{\circ} \mathrm{C}$ for $10 \mathrm{~min}$. The mixture was sonicated for $5 \mathrm{~min}$ and pulled on to a new tube. Finally, the SpeedVac was used to dry the samples.

Protein identification. Peptides were analysed by LC-MS/ MS (Waters, Micromass Q-Tof micro ${ }^{\mathrm{TM}}$ ). Electrospray ionisation quadrupole-time of flight (Column C18, $300 \mu \mathrm{m}$ by $15 \mathrm{~cm}$ ) mass spectrometry was used to analyse the amino acid sequences of the tryptic peptides. The standard peptide (Glu-fiblinopeptide) was injected into the capillary column and afterwards a peptide sample of protein spot was also injected into the same capillary column. Peptides were separated by 2 eluents, including eluent A (3\% ACN, $0.1 \%$ formic acid in $\mathrm{H}_{2} \mathrm{O}$ ) and eluent $\mathrm{B}(0.1 \%$ formic acid in $97 \%$ $\mathrm{ACN})$. Ninety-three percent of $\mathrm{A}$ and $7 \%$ of $\mathrm{B}$ were used at 0 min, $50 \%$ of $A$ and B at $35 \mathrm{~min}, 20 \%$ of $A$ and $80 \%$ of B at 45 and 49 min respectively, and $93 \%$ of A and $7 \%$ of B at 50 and $60 \mathrm{~min}$, respectively.

The system was run until the peptide separation finished. The monoisotopic peptide masses for all samples were measured and then searched into the search engine MASCOT (Matrix Science, London, UK). The data were searched 
A

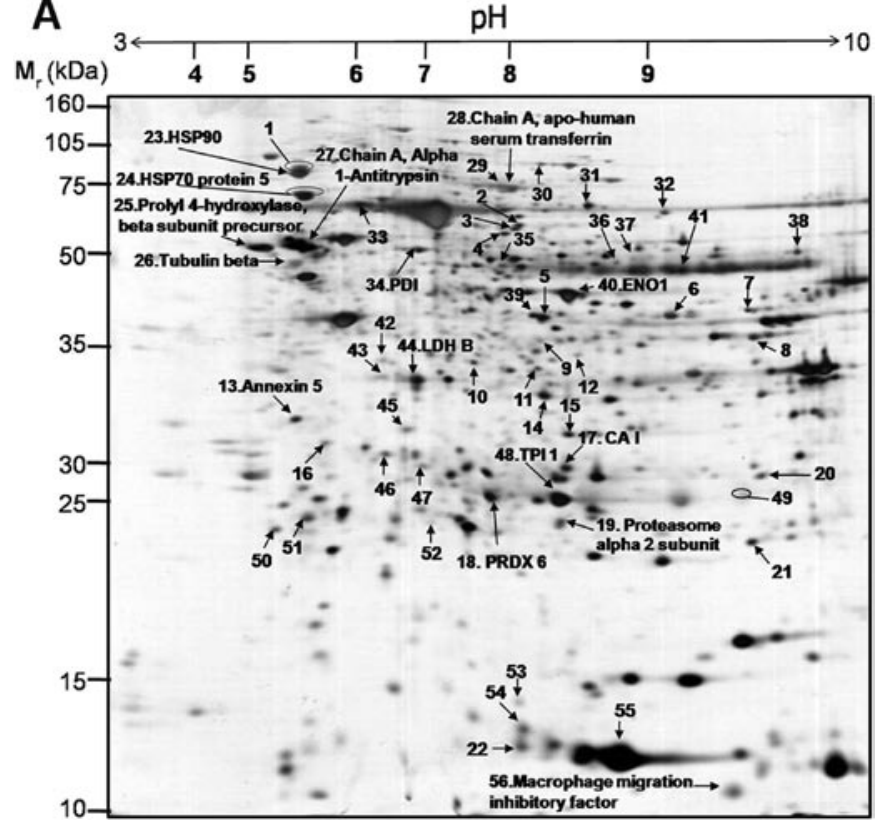

B

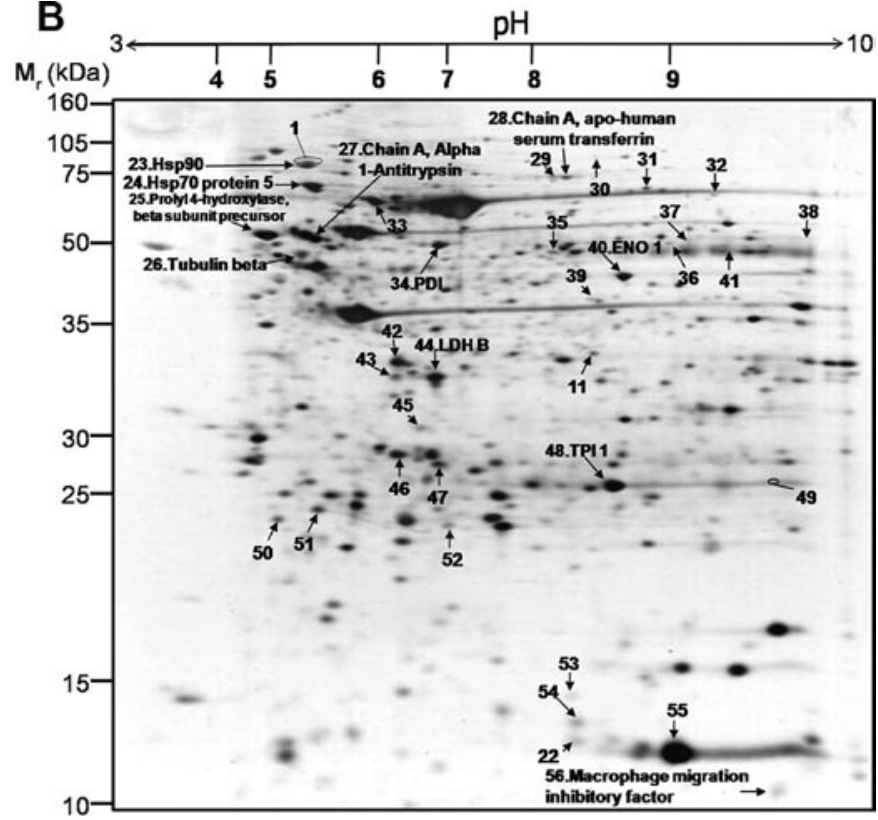

Figure 1. Representative silver-stained 2D-gels of a primary breast tumor (A) and its matched ALN metastasis (B). Differentially expressed proteins are labeled numerically. Spots 1-22 are differentially expressed proteins between node-negative breast tumor and node-positive breast tumor. Spots 1 , 11, 22-56 are differentially expressed proteins between primary breast tumor and metastatic ALN. Successfully identified proteins are shown as protein names. CA I, carbonic anhydrase I ; ENO1, enolase 1; LDH B, lactate dehydrogenase B; PRDX 6, peroxiredoxin 6; PDI, protein disulfide isomerase; TPI 1, triosephosphate isomerase 1 .

against NCBI non-redundant protein sequence database. The variable modifications (phospho ST), mass values (monoisotopic), protein mass (unrestricted), peptide mass tolerance $( \pm 1.2 \mathrm{Da})$ and fragment mass tolerance $( \pm 0.2 \mathrm{Da})$ were included in the search parameters. A maximum of one trypsin missed cleavage was allowed. Protein identifications were considered to be correct when the protein score was greater than based Mowse score $(\mathrm{p}<0.05)$.

Immnuhistochemistry. Validation study was performed using immunohistochemical staining for $\beta$-tubulin on formalinfixed, paraffin-embedded sections. The three-micrometer sections were incubated at $45^{\circ} \mathrm{C}$ overnight. The sections were deparaffinized by xylene and rehydrated in graded alcohol. Antigen was retrieved by immersing the sections in Tris EDTA buffer $\mathrm{pH} 9.0$ in a pressure cooker at $95^{\circ} \mathrm{C}$ for $4 \mathrm{~min}$. Endogenous peroxidase activity was blocked with $3 \% \mathrm{H}_{2} \mathrm{O}_{2}$ for $5 \mathrm{~min}$ and the sections were then washed in distilled water and immersed in PBS buffer $\mathrm{pH} 7.6$ for $5 \mathrm{~min}$. To block non-specific proteins, the sections were incubated with $3 \%$ normal horse serum in moist chamber for $30 \mathrm{~min}$. The sections were incubated with the antibody against $\beta$-tubulin (clone TBN06, NeoMarkers, Fremont, CA, USA) ready to use. The antibody reactions were revealed using EnVision ${ }^{\mathrm{TM}}$ system (Dako-Cytomation, Glostrup, Denmark) according to the manufacturer's instruction. Subsequently the sections were incubated in DAB chromogen for 5 min, counterstained with hematoxylin and mounted. Immunoreactivity was evaluated under light microscopy. Sections that incubation with the primary antibody had been omitted were used as a negative control. IHC staining was evaluated under light microscopy and the intensity was scored as 0 (negative), $1+$ (weak), 2+ (moderate), and 3+ (strong). Cases were considered positive if $10 \%$ or more of the tumor cells showed unequivocal immunoreactivity.

\section{Results}

Cases. Eleven cases of breast cancer in women aged 36-76 years were included in the study. The details of the clinicopathological features are shown in Table I. Five cases were node-negative breast cancers, of which two cases were ductal carcinoma in situ. Six cases were node-positive breast disease.

$2 D$-gel electrophoresis and image analysis. The 2D-gel that contained the most abundant protein spots detected by Image master 2D-platinum was used as reference. This reference gel revealed a total of 678 protein spots. The protein intensities of all 678 spots in all gels were estimated. The data were analyzed for two sets of comparisons: i) breast tumor tissue from node-negative disease $\left(\mathrm{Tn}^{-}, \mathrm{n}=5\right.$ samples) vs. breast tumor tissue from node-positive disease $\left(\mathrm{Tn}^{+}, \mathrm{n}=6\right.$ samples) using t-test; and ii) breast tumor tissue from node-positive disease $\left(\mathrm{Tn}^{+}, \mathrm{n}=5\right.$ samples), and their lymph node metastases (L, $\mathrm{n}=5$ samples) using paired t-test.

Twenty-two protein spots were differentially expressed between $\mathrm{Tn}^{+}$vs. $\mathrm{Tn}^{-}$(Fig. 1). Nineteen proteins were up-regulated and three proteins were down-regulated in $\mathrm{Tn}^{+}$compared to $\mathrm{Tn}^{-}$. Thirty-seven protein spots were differentially expressed between $\mathrm{L}$ vs. $\mathrm{Tn}^{+}$. Fourteen proteins were up-regulated and 23 proteins were down-regulated in $\mathrm{L}$ compared to their primary breast tumors.

Identification of altered proteins. Protein spots that were statistically different which showed consistent expression 
A

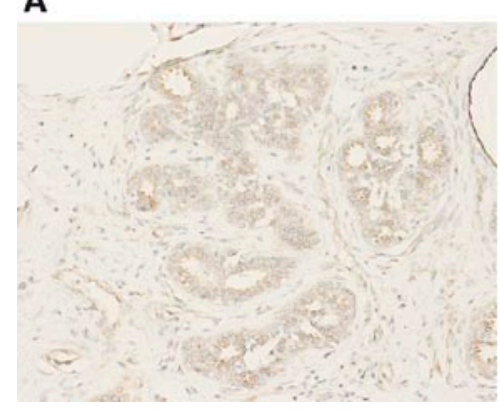

B



C

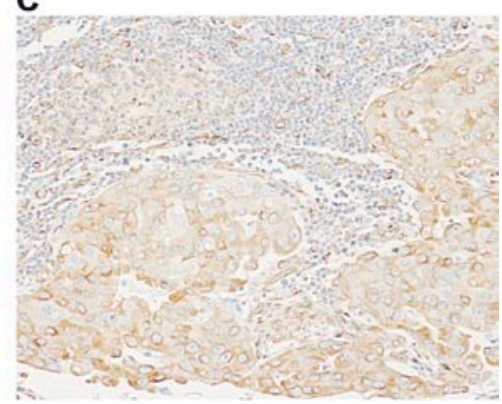

Figure 2. Immunohistochemistry analysis for $\beta$-tubulin showing gradual increase in staining intensity from normal breast (A), primary tumor (B) and ALN metastasis (C). Light microscopy, x200.

primary breast tumors and their matched ALN metastasis. We also compared primary tumors between node-negative and node-positive breast cancers. Our results have identified eleven proteins differentially expressed between the comparison groups. These proteins involved stress response, apoptosis, protein synthesis/degradation, homeostasis, cell migration and immune defense. Some of the proteins have been reported in previous study comparing breast tumor and normal tissue (10-12).

The results from 2D-SDS-PAGE showed a very similar protein expression profiles in primary tumor and matched ALN and between tumors with and without ALN metastases. The results are consistent with previous proteomic studies (13-15). These findings are also consistent with genomic profiling studies comparing primary tumors and their matched metastatic ALN $(14,15)$. This suggests that key biological characteristics of primary breast cancer cells are maintained in metastatic cancer cells. However, in spite of the striking overall similarities observed, we detected a few significant altered proteins between the comparison sets. Thirty-seven protein spots among 678 $(5.45 \%)$ detected spots were differentially expressed between primary tumors and their metastatic ALN and 22 spots among 678 spots $(3.24 \%)$ between primary tumors with and without ALN metastases. Compared to the study of Vydra et al (14), we found a greater number of total protein spots in 2D images (678 vs. 245 spots) and a higher proportion of significant differential proteins (5.45 vs. $1.22 \%$ ). This may be due to the different samples used in the analyses (clinical samples vs. cultured cells).

Highly proliferative cells and cells exposed to new environments suffer from various cellular stresses. The present study identified at least four stress-response proteins: heat shock 70-kDa protein 5 (HSPA5), 90-kDa heat shock protein (HSP90), protein disulfide isomerase (PDI) and prolyl 4-hydroxylase $\beta$ subunit precursor. HSPA5 (also known as glucose-regulated protein GRP78) is a major molecular chaperone at the endoplasmic reticulum (ER) (16). Because of its anti-apoptotic properties, it is a key pro-survival component of the unfolded protein response (17). HSPA5 has been reported to be up-regulated in breast cancer compared to normal tissue $(10,11,18)$. In the present study, HSPA5 was up-regulated in metastatic ALN, supporting the theory that HSPA5 plays a role in the protection of metastatic cells in new adverse environments.
HSP90 also has anti-apoptotic properties, and is known to promote cancer cell growth or survival by activating and maintaining the function of major cellular proteins (19). HSP90 was demonstrated as protein and RNA levels to be up-regulated in breast cancer tissue compared to non-cancer tissues $(12,20)$. This protein has been found to be associated with decreased survival in breast cancer (21). However, in the present study, HSP90 was down-regulated in metastatic ALN compared to primary tumors. This finding can not be explained based on current knowledge.

Protein disulfide isomerase (PDI) is an enzyme involved in processing and maturation of secretory proteins in endoplasmic reticulum. The $\beta$ subunit of Prolyl 4-hydroxylase has been found to be identical to the PDI (22). Schultz-Norton et al found that PDI functioned as ER- $\alpha$ chaperones in breast cancer cells (23). It increased the capacity of ER to bind to DNA, enhanced ER-ERE complex formation after exposure to the oxidizing agent. As estrogen binding to an estrogen receptor is critical for breast cancer cell growth, PDI might play a role on survival of metastatic breast cancers in axillary node via an action of ER- $\alpha$ chaperones.

The present study found overexpression of $\beta$-tubulin in metastatic tumors compared to their primary tumors. This was validated by immunohistochemical staining in tissue sections. Tubulin is a major component of microtubules, important cellular cytoskeletons which have various cell function including cell growth and division, maintenance of cell shape, transport of intracellular vesicles and organelles and cellular signaling (24). Overexpression of $\beta$-tubulin in metastatic tumor suggests that metastasized tumor cells utilize microtubule functions, many of which involve in metastatic cascade. Studies in other cancers also demonstrate invasive and metastatic roles of $\beta$-tubulin $(25,26)$.

Since reactive oxygen species (ROS) are usually found in increased numbers in cancer cells, peroxiredoxin (PRDX), an enzyme that detoxifies hydrogen peroxide and various peroxides is expected to be overexpressed. One previous study reported expression of peroxiredoxin isoforms I-VI in 52-94\% of breast carcinomas (27). Our findings show that PRDX6 was up-regulated in advanced staged tumors supporting the theory of increased ROS in cancer cells during tumor progression.

In early apoptosis, phosphatidylserine exposes itself on the surface of the dying cells to trigger clearance. Annexin A5 (or Annexin V) binds with high affinity and specificity 
to phosphatidylserine, causing a reduction in the clearance of dying cells and consequently interfering with the immunosuppressive effects of apoptotic cells (28). It has also been shown in vivo study that impaired clearance of dying tumor cells can lead to tumor rejection (29). In contrast to the evidence of these studies, Annexin A5 was found to be up-regulated in tumors with ALN metastasis in the present study, consistent with report of other cancers (30). Most recently, Annexin A5 has been demonstrated to have possible influence on proliferation and invasion capacity of cancer cells via deregulation of the genes implicated in cell motility (31).

Proteasome $\alpha 2$ subunit, a subunit of proteosome, functions in degradation of damaged proteins by proteolysis (32). Previous studies have reported alteration of proteasome subunit $\alpha$ type 1 in infiltrating breast carcinomas (11). In this study, proteasome $\alpha 2$ subunit was up-regulated, indicating increased damage to proteins in cancer cells.

Previous studies have shown that growing cancer cells increased in both aerobic as well as anaerobic glycolyses through their exposure to physiological stresses $(33,34)$. Supporting this basis, the present study revealed up-regulation of triosephosphate isomerase 1 and lactate dehydrogenase B, enzymes involved in these two processes, in metastatic ALN. These suggest that metastatic cells have higher levels of physiological stress. Up-regulation of carbonic anhydrase I, a zinc-containing metalloenzyme, which maintain $\mathrm{pH}$ homeostasis and ion transport also supports the increased metabolism of tumor cells (35). Carbonic anhydrase I was also reported to be up-regulated in breast cancer tissue compared to normal tissue in a proteomic study (12). Many carbonic anhydrase inhibitors have been shown to inhibit tumor cell proliferation in vitro, including breast cancer cell lines (36).

Iron is essential for proliferation of normal and neoplastic cells (37). In vivo studies have demonstrated that excess iron, with its capability of generating ROS, may contribute to malignant transformation, increased metastasis and invasiveness of various cancers including breast cancer $(38,39)$. Net iron equilibrium requires both apotransferrin and ferrotransferrin (40). The present study found down-regulation of chain A apo-human serum transferrin (chain A apo-hTF), a transferrin without iron. This may disrupt iron equilibrium and promote cell proliferation. However, the exact role of chain A apo-hTF on tumor cell proliferation and metastasis needs more investigation.

Others differentially expressed proteins found in the present study included $\beta$-tubulin, chain A $\alpha 1$-antitrypsin, enolase 1 , and macrophage migration inhibitory factor (MIF). Up-regulation of $\beta$-tubulin, a major protein in mitotic spindles, suggests enhanced cancer cell division. Chain A $\alpha 1$-antitrypsin is a serine proteases inhibitor. Serine proteases are known as an extracellular matrix degrader (41). Down-regulation of chain A $\alpha 1$-antitrypsin found in the present study, may indicate enhanced function of serine proteases to degrade extracellular matrix. Enolase 1 (also known as $\alpha$-enolase), is a glycolytic enzyme expressed in most tissues. More recent evidence has shown that enolase also functions as a plasminogen receptor (42) and may also play a role in tissue invasion (43). Increased enolase 1 expression has been demonstrated in various cancers including breast cancer (44). In the current study, enolase 1 was found to be down-regulated in metastastic ALN compared to primary tumor, consistent with those previous reports.

Macrophage migration inhibitory factor (MIF) was found to be down-regulated in metastatic ALN. MIF is a pleiotropic cytokine and mediator of acute and chronic inflammatory diseases. Many studies revealed contradictory effects of MIF on tumor biology. Overexpression of MIF was reported in various cancers including breast cancer (45-47). However, Pozzi and Weiser demonstrated that recombinant MIF can activate macrophages which became cytotoxic for tumor cells in vitro (48). Most recently, Verjans et al have reported a dual role of MIF in human breast cancer depending whether it is intracellular or extracelluar expression (49). Collectively the evidence suggests that expression of MIF in breast cancer is a complex situation and has different effects on tumor biology.

Certain limitations of the present study should be noted. The 2D-PAGE technology requires a large amount of protein extract. If there are only small subpopulations of tumor cells within the primary site with higher metastatic potential, altered proteins may not be detected. Selection bias for protein identification may occur because sharp and sizable protein spots in 2D gel were more likely to be selected for further protein identification and small protein spots were not obtained. And finally, the present study included only a small number of samples and thus some altered proteins may not have been statistically different. Even with these limitations, however, we successfully identified 15 proteins, all of which are associated with tumor cell growth and survival. To our best knowledge, this is the second comparative proteomic study in primary breast tumor vs. matched metastatic ALN. However, our results need further studies to determine whether these proteins are observable on traditional IHC as well as their clinical usefulness.

\section{Acknowledgements}

We thank Associate Professor Puttisak Puttawibul for clinical specimens and the Department of Anatomy, Faculty of Science for 2D gel facilities. We specially thank Professor M.R. Jisnuson Svasti and Associate Professor Chidchanok Leethanakul for their critical discussions on the results. We thank Dave Patterson and Christopher Gary Dunn for English proof. This study was supported by Prince of Songkla University.

\section{References}

1. Parkin DM, Bray F, Ferlay J and Pisani P: Global cancer statistics, 2002. CA Cancer J Clin 55: 74-108, 2005.

2. Vatanasapt V, Martin N, Siriplung H, Chindavijak K, Sontipong S, Sriamporn S and Parkin DM: Cancer in Thailand 1988-1991. The international Agency for Research on Cancer, Lyon, pp68, 1993.

3. Khuhaprema T, Srivatanakul P, Attasara P, Sriplung H, Wiangnon S and Sumitsawan Y: Cancer in Thailand. Vol. 5. 2001-2003. Bangkok, pp47, 2010.

4. Carter CL, Allen C and Henson DE: Relation of tumor size, lymph node status, and survival in 24,740 breast cancer cases. Cancer 63: 181-187, 1989.

5. Fisher ER, Anderson S, Tan-Chiu E, Fisher B, Eaton L and Wolmark N: Fifteen-year prognostic discriminants for invasive breast carcinoma: National Surgical Adjuvant Breast and Bowel Project Protocol-06. Cancer 91 (8 Suppl): 1679-1687, 2001. 
6. Loeb LA, Loeb KR and Anderson JP: Multiple mutations and cancer. Proc Natl Acad Sci USA 100: 776-781, 2003.

7. Hanahan D and Weinberg RA: The hallmarks of cancer. Cell 100: 57-70, 2000.

8. Hanash SM: Global profiling of gene expression in cancer using genomics and proteomics. Curr Opin Mol Ther 3: 538-545, 2001.

9. Greene FL, Page DL, Fleming ID, Fritz A, Balch CM, Haller DG and Morrow M: AJCC Cancer Staging Manual. 6th edition. Springer, New York, pp171-180, 2002.

10. Wulfkuhle JD, Sgroi DC, Krutzsch H, McLean K, McGarvey K, Knowlton M, Chen S, Shu H, Sahin A, Kurek R, Wallwiener D, Merino MJ, Petricoin EF III, Zhao Y and Steeg PS: Proteomics of human breast ductal carcinoma in situ. Cancer Res 62 : 6740-6749, 2002.

11. Deng SS, Xing TY, Zhou HY, Xiong RH, Lu YG, Wen B, Liu SQ and Yang HJ: Comparative proteome analysis of breast cancer and adjacent normal breast tissues in human. Genomics Proteomics Bioinformatics 4: 165-172, 2006.

12. Luo Y, Zhang J, Liu Y, Shaw AC, Wang X, Wu S, Zeng X, Chen J, Gao Y and Zheng D: Comparative proteome analysis of breast cancer and normal breast. Mol Biotechnol 29: 233-244, 2005.

13. Nakagawa T, Huang SK, Martinez SR, Tran AN, Elashoff D, Ye X, Turner RR, Giuliano AE and Hoon DS: Proteomic profiling of primary breast cancer predicts axillary lymph node metastasis. Cancer Res 66: 11825-11830, 2006.

14. Vydra J, Selicharová I, Smutná K, Sanda M, Matousková E, Bursíková E, Prchalová M, Velenská Z, Coufal D and Jirácek J: Two-dimensional electrophoretic comparison of metastatic and non-metastatic human breast tumors using in vitro cultured epithelial cells derived from the cancer tissues. BMC Cancer 8: $107,2008$.

15. Li J, Gromov P, Gromova I, Moreira JM, TimmermansWielenga V, Rank F, Wang K, Li S, Li H, Wiuf C, Yang H Zhang X, Bolund L and Celis JE: Omics-based profiling of carcinoma of the breast and matched regional lymph node metastasis. Proteomics 8: 5038-5052, 2008.

16. Hendershot LM: The ER function $\mathrm{BiP}$ is a master regulator of ER function. Mt Sinai J Med 71: 289-297, 2004.

17. Kaufman RJ: Orchestrating the unfolded protein response in health and disease. J Clin Invest 110: 1389-1398, 2002.

18. Fernandez PM, Tabbara SO, Jacobs LK, Manning FC, Tsangaris TN, Schwartz AM, Kennedy KA and Patierno SR: Overexpression of the glucose-regulated stress gene GRP78 in malignant but not benign human breast lesions. Breast Cancer Res Treat 59: 15-26, 2000.

19. Neckers L and Ivy SP: Heat shock protein 90. Curr Opin Oncol 15: 419-424, 2003

20. Yano M, Naito Z, Yokoyama M, Shiraki Y, Ishiwata T, Inokuchi $\mathrm{M}$ and Asano G: Expression of hsp90 and cyclin D1 in human breast cancer. Cancer Lett 137: 45-51, 1999.

21. Pick E, Kluger Y, Giltnane JM, Moeder C, Camp RL, Rimm DL and Kluger HM: High HSP90 expression is associated with decreased survival in breast cancer. Cancer Res 67: 2932-2937, 2007.

22. Kivirikko KI, Myllylä R and Pihlajaniemi T: Protein hydroxylation: prolyl 4-hydroxylase, an enzyme with four cosubstrates and a multifunctional subunit. FASEB J 3: 1609-1617, 1989.

23. Schultz-Norton JR, McDonald WH, Yates JR and Nardulli AM: Protein disulfide isomerase serves as a molecular chaperone to maintain estrogen receptor alpha structure and function. Mol Endocrinol 20: 1982-1995, 2006.

24. Cleveland DW and Sullivan KF: Molecular biology and genetics of tubulin. Annu Rev Biochem 54: 331-365, 1985.

25. Portyanko A, Kovalev P, Gorgun J and Cherstvoy E: beta(III)tubulin at the invasive margin of colorectal cancer: possible link to invasion. Virchows Arch 454: 541-548, 2009.

26. He ZY, Wen H, Shi CB and Wang J: From Up-regulation of hnRNP A1, Ezrin, tubulin $\beta-2 \mathrm{C}$ and Annexin A1 in sentine lymph nodes of colorectal cancer. World J Gastroenterol 16: 4670-4676, 2010.

27. Karihtala P, Mäntyniemi A, Kang SW, Kinnula VL and Soini Y: Peroxiredoxins in breast carcinoma. Clin Cancer Res 9: $3418-3424,2003$
28. Munoz LE, Franz S, Pausch F, Fürnrohr B, Sheriff A, Vogt B, Kern PM, Baum W, Stach C, von Laer D, Brachvogel B, Poschl E, Herrmann M and Gaipl US: The influence on the immunomodulatory effects of dying and dead cells of Annexin V. J Leukoc Biol 81: 6-14, 2007.

29. Bondanza A, Zimmermann VS, Rovere-Querini P, Turnay J, Dumitriu IE, Stach CM, Voll RE, Gaipl US, Bertling W, Pöschl E, Kalden JR, Manfredi AA and Herrmann M: Inhibition of phosphatidylserine recognition heightens the immunogenicity of irradiated lymphoma cells in vivo. J Exp Med 200: 1157-1165, 2004.

30. Kang HJ, Koh KH, Yang E, You KT, Kim HJ, Paik YK and Kim H: Differentially expressed proteins in gastrointestinal stromal tumors with KIT and PDGFRA mutations. Proteomics 6: 1151-1157, 2006.

31. Wehder L, Arndt S, Murzik U, Bosserhoff AK, Kob R, von Eggeling $F$ and Melle C: Annexin A5 is involved in migration and invasion of oral carcinoma. Cell Cycle 8: 1552-1558, 2009.

32. Ciechanover A: The ubiquitin-proteasome proteolytic pathway. Cell 79: 13-21, 1994.

33. Warburg O: On the origin of cancer cells. Science 123: 309-314, 1956.

34. Koukourakis MI, Giatromanolaki A, Harris AL and Sivridis E: Comparison of metabolic pathways between cancer cells and stromal cells in colorectal carcinomas: a metabolic survival role for tumor-associated stroma. Cancer Res 66: 632-637, 2006.

35. Tashian RE: Genetics of the mammalian carbonic anhydrases Adv Genet 30: 321-356, 1992.

36. Scozzafava A and Supuran CT: Carbonic anhydrase inhibitors: synthesis of N-morpholylthiocarbonylsulfenylamino aromatic/ heterocyclic sulfonamides and their interaction with isozymes I, II and IV. Bioorg Med Chem Lett 10: 1117-1120, 2000.

37. Le NT and Richardson DR: The role of iron in cell cycle progression and the proliferation of neoplastic cells. Biochim Biophys Acta 1603: 31-46, 2002.

38. Benhar M, Engelberg D and Levitzki A: ROS, stress-activated kinases and stress signaling in cancer. EMBO Rep 3: 420-425, 2002.

39. Kim DH, Kim JH, Kim EH, Na HK, Cha YN, Chung JH and Surh YJ: 15-Deoxy-Delta12,14-prostaglandin J2 upregulates the expression of heme oxygenase-1 and subsequently matrix metalloproteinase-1 in human breast cancer cells: possible roles of iron and ROS. Carcinogenesis 30: 645-654, 2009.

40. Young SP, Fahmy M and Golding S: Ceruloplasmin, transferrin and apotransferrin facilitate iron release from human liver cells. FEBS Lett 411: 93-96, 1997

41. Kueppers F: $\alpha 1$-Antitrypsin. Am J Hum Genet 25: 677-686, 1973.

42. Redlitz A, Fowler BJ, Plow EF and Miles LA: The role of an enolase-related molecule in plasminogen binding to cells. Eur J Biochem 227: 407-415, 1995.

43. Liu KJ and Shih NY: The role of enolase in tissue invasion and metastasis of pathogens and tumor cells. J Cancer Mol 3: 45-48, 2007.

44. Altenberg B and Greulich KO: Genes of glycolysis are ubiquitously overexpressed in 24 cancer classes. Genomics 84: 1014-1020, 2004

45. Meyer-Siegler K and Hudson PB: Enhanced expression of macrophage migration inhibitory factor in prostatic adenocarcinoma metastases. Urology 48: 448-452, 1996.

46. Kamimura A, Kamachi M, Nishihira J, et al: Intracellular distribution of macrophage migration inhibitory factor predicts the prognosis of patients with adenocarcinoma of the lung. Cancer 89: 334-341, 2000

47. Bini L, Magi B, Marzocchi B, et al: Protein expression profiles in human breast ductal carcinoma and histologically normal tissue. Electrophoresis 18: 2832-2841, 1997.

48. Pozzi LA and Weiser WY: Human recombinant migration inhibitory factor activates human macrophages to kill tumor cells. Cell Immunol 145: 372-379, 1992.

49. Verjans E, Noetzel E, Bektas N, et al: Dual role of macrophage migration inhibitory factor (MIF) in human breast cancer. BMC Cancer 9: 230, 2009. 